\title{
UPAYA MENINGKATKAN KEMAMPUAN BERPIDATO DENGAN MENGGUNAKAN METODE DEMONTRASI SISWA KELAS VI SD NEGERI 1 KUKUH KERAMBITAN TAHUN PELAJARAN 2009/2010
}

\author{
Ni Made Sueni, I Wayan Nardi, Ni Kadek Ria Padmadewi \\ IKIP Saraswati Tabanan
}

\begin{abstract}
This study aims at obtaining the objective description about the improvement of speech ability using demonstration method of six grade students of SD Negeri 1 Kukuh Kerambitan in academic year 2009/2010. This study is classroom action research which consists of two cycles with 14 students. Each cycle consists of 4 stages : they are (1) planning, (2) action, (3) observation and evaluation, (4) reflection. Based on the data analysis, there was a significant improvement of speech ability of six grade students of SD Negeri 1 Kukuh Kerambitan. It is proved by the result of pretest with the average 55. 71 . After that, it was followed by the test on the cycle I with average 64.29, then increased to 76.43 on cycle II. As a result, the improvement from cycle I to cycle II is 12.14. Therefore, it can be suggested to the Indonesian language teachers to apply demonstration method in the learning process.
\end{abstract}

Keywords: speech, demonstration method.

\section{PENDAHULUAN}

Keterampilan berbicara (berpidato) merupakan keterampilan berbahasa yang sangat penting bagi siswa, baik yang masih duduk di bangku sekolah maupun yang sudah tamat dan bahkan yang sudah terjun di masyarakat. Berbicara (berpidato) merupakan keterampilan berbahasa lisan. Untuk mewujudkan keterampilan berbicara terlebih dahulu harus memahami bahasa lisan lewat mendengarkan. Berbicara dan mendengarkan merupakan dua keterampilan yang saling berkaitan satu sama lain. Dua keterampilan lain yaitu membaca dan menulis juga merupakan bagian dari keterampilan berbahasa. Jadi, keterampilan berbahasa memiliki empat aspek keterampilan yaitu menyimak, berbicara, membaca, dan menulis. Keempat aspek keterampilan berbahasa ini saling berkaitan satu sama lainnya tidak bisa dipisahpisahkan.

Berpidato merupakan salah satu bagian dari keterampilan berbicara dan salah satu cara meningkatkan kemampuan berpikir dan berkomunikasi. Oleh jarena itu 
semakin baik bahasa seseorang, semakin baik pula jalan pikirannya. Orang dapat mengungkapkan buah pikirannya dengan lancar bila penguasaan bahasanya baik. Sebaliknya bila kemampuan berpikir seseorang rendah, bahasa yang diungkapkannya juga amburadul. Berdasarkan pengamatan penulis di Sekolah Dasar Negeri 1 Kukuh Kerambitan, kemampuan siswa di dalam berpidato sangat kurang. Oleh karena itu penulis tertarik untuk meneliti masalah ini dengan menggunakan metode demonstrasi.

Permasalahan yang ingin dirumuskan dalam penelitian ini adalah (1) bagaimanakah kemampuan berpidato siswa kelas VI Sekolah Dasar Negeri 1 Kukuh Kerambitan tahun pelajaran 2009/2010 sebelum menggunakan metode demonstrasi? (2) Bagaimanakah kemampuan berpidato siswa Sekolah Dasar Negeri 1 Kukuh Kerambitan sesudah menggunakan metode demonstrasi? (3) Seberapa besar peningkatan kemampuan berpidato siswa Sekolah Dasar Negeri 1 Kukuh Kerambitan sesudah menggunakan metode demonstrasi?

Penelitian ini dilakukan dengan tujuan: (1) untuk mengetahui kemampuan berpidato siswa Sekolah Dasar Negeri 1 Kukuh Kerambitan sebelum menggunakan metode demonstrasi. (2) untuk mengetahui kemampuan berpidato siswa Sekolah Dasar Negeri 1 Kukuh Kerambitan sesudah menggunakan metode demonstrasi. (3) untuk mengetahui peningkatan kemampuan berpidati siswa Sekolah Dasar Negeri 1 Kukuh Kerambitan setelah menggunakan metode demonstrasi.

Dalam penelitian ini, hal-hal yang dinilai dalam berpidato siswa adalah keterampilan ucapan, diksi atau pilihan kata, gerak-gerik dan mimik, penguasaan topik dan kelancaran berpidato.

\section{Teori dan Hipotesis}

\section{Pengertian Berpidato}

Firmansyach (2003: 9) menyatakan "Pidato adalah penyampaian gagasan, pikiran atau informasi serta tujuan dari pembicaraan (orang yang berpidato) kepada orang banyak (orang yang mendengarkan) secara lisan dengan cara-cara tertentu." Sedangkan Suhendar (1992:102) berpendapat "berpidato merupakan kegiatan berbicara satu arah, yang lebih resmi dan formal". Berdasarkan pengertian di atas, 
berpidato adalah suatu pembicaraan yang mengandung suatu pesan atau informasi kepada para pendengar.

\section{Tujuan Berpidato}

Tujuan dari sebuah pidato dapat dibedakan menjadi beberapa jenis. Firmansyach (2003:12) membagi tujuan berpidato menjadi 3 yaitu: (1) bertujuan memberitahukan, (2) bertujun untuk menghibur, (3) bertujuan untuk mempengaruhi atau membujuk.

Pidato yang bertujuan untuk memberikan sesuatu kepada para pendengar, mengharapkan para pendengar paham dan mengerti apa yang telah disampaikan oleh pembicara. Sedangkan pidato yang bertujuan untuk menghibur mengharapkan para pendengar merasa puas dan terhibur dengan apa yang disampaikan oleh pembicara. Pidato ini dapat diselipi sedikit humor-humor segar yang spontanitas agar pendengar senang dan tidak tegang. Pidato yang bertujuan mempengaruhi atau membujuk para pendengar, dilakukan dengan mendorong, meyakinkan, dan mengajak para pendengar untuk melakukan sesuatu hal yang sesuai dengan keinginan pembicara baik berupa seruan atau tindakan.

\section{Pengertian Metode Demonstrasi}

Metode demonstrasi adalah metode penyajian pelajaran dengan memperagakan dan mempertunjukkan kepada siswa tentang suatu proses, situasi atau benda tertentu, baik sebenarnya atau hanya sekedar tiruan (Sanjaya, 2006:152). Sumanti dkk (1999:154) mengungkapkan bahwa metode demonstrasi adalah suatu penyajian pelaran dengan memperagakan dan mempertunjukkan kepada peserta didik suatu proses, situasi atau benda tertentu yang sedang dipelajari baik dalam bentuk sebenarnya maupun dalam bentuk tiruan yang dipertunjukkan oleh guru atau sumber belajar lain yang memahami atau ahli dalam topik bahasan yang akan didemonstrasikan.

Berdasarkan pengertian di atas, bahwa metode demonstrasi adalah metode sederhana yang mempertunjukkan, memperagakan suatu proses atau suatu bentuk melalui belajar secara langsung kepada peserta didik. 


\section{Kelebihan dan Kelemahan Metode Demonstrasi}

Kelebihan Metode Demonstrasi

1. Melalui metode demonstrasi terjadinya verbalisme dapat dihindari, sebab siswa langsung memperhatikan bahan pelajaran yang dijelasikan.

2. Proses pembelajaran lebih menarik.

3. Dengan mengamati secara langsung siswa memiliki kesempatan membandingkan antara teori dan kenyataan.

Kelemahan Metode Demonstrasi

1. Demonstrasi memerlukan persiapan yang lebih matang, tanpa persiapan yang memadai demonstrasi bisa gagal sehingga menyebabkan metode ini tidak efektif lagi.

2. Demonstrasi memerlukan peralatan, bahan-bahan dan tempat yang memadai yang berarti penggunaan metode ini memerlukan biaya yang lebih mahal.

3. Demonstrasi memerlukan kemampuan dan keterampilan guru yang khusus, sehingga guru dituntut bekerja lebih profesional.

Berdasarkan uraian di atas indikator penerapan metode demonstrasi mencakup: (1) kegiatan yang merangsang siswa untuk berpikir, (2)suasana pembelajaran, (3) reaksi siswa, dan (4) kreativitas siswa.

\section{Hipotesis Tindakan}

Terkait dengan topik tulisan ini, penulis kemukakan hipotesis yang mendasari dan mengarahkan seluruh proses penelitian ini. Hipotesis yang akan dibuktikan kebenarannya dalam penelitian ini adalah penggunaan metode demonstrasi dapat meningkatkan kemampuan berpidato siswa Sekolah Dasar Negeri 1 Kukuh Kerambitan tahun pelajaran 2009/2010.

\section{METODE PENELITIAN}

Penelitian ini termasuk penelitian tindakan kelas yang bermaksud untuk meningkatkan kemampuan berpidati siswa Sekolah Dasar Negeri 1 Kukuh Kerambitan melalui metode demontrasi. Tindakan yang akan dilakukan adalah pemanfaatan metode demontrasi dalam berpidato. 
Penelitian tindakan kelas ini menggunakan rancangan model Kemmis yang terdiri dari 4 langkah yaitu perencanaan, pelaksanaan, observasi, dan refleksi. Penelitian ini dilaksanakan dalam 2 siklus dengan rancangan tindakan sebagai berikut.

Siklus $\mathrm{I} \rightarrow$ refleksi awal $\rightarrow$ perencanaan tindakan $\mathrm{I} \rightarrow$ pelaksanaan tindakan I $\rightarrow$ obsevasi dan evaluasi $\rightarrow$ refleksi siklus I $\rightarrow$ siklus II $\rightarrow$ perencanaan tindakan II $\rightarrow$ pelaksanaan tindakan II $\rightarrow$ obsevasi dan evaluasi $\rightarrow$ refleksi siklus II $\rightarrow$ memutuskan tindakan terbaik.

Data penelitian ini dikumpulkan dengan metode tes dan observasi. Metode tes digunakan untuk mendapatkan data penelitian melalui penyampaian sejumlah pertanyaan atau tes. Hal ini sesuai dengan pendapat Arikunto (1992:127) yang menyatakan bahwa tes adalah "serentetan pertanyaan atau latihan serta alat lain yang digunakan untuk mengukur keterampilan pengetahuan intelegensi, kemampuan atau bakat yang dimiliki oleh individu atau kelompok." Penggunaan tes ini dimaksudkan untuk mendapatkan data berupa nilai yang akan menunjukkan bagaimana tingkat penguasaan siswa tentang berpidato. Tes yang dimaksud di sini adalah tes berpidato.

Aspek-aspek yang dinilai dalam berpidato siswa Sekolah Dasar Negeri 1 Kukuh Kerambitan adalah seperti berikut.

Tabel 1. Aspek-aspek Penilaian

\begin{tabular}{|c|l|c|}
\hline No & \multicolumn{1}{|c|}{ Aspek-aspek yang dinilai } & Skor \\
\hline 1 & Ketepatan ucapan & 20 \\
\hline 2 & Diksi atau pilihan kata & 20 \\
\hline 3 & Gerak-gerik dan mimik & 20 \\
\hline 4 & Penguasaan topik & 20 \\
\hline 5 & Kelancaran & 20 \\
\hline \multicolumn{2}{|c|}{ Total skor } & 100 \\
\hline
\end{tabular}

Sedangkan observasi dilakukan terhadap penggunaan metode demonstrasi dalam berpidato. Aspek-aspek yang diobservasi seperti berikut ini. 
Tabel 2. Aspek-aspek Observasi

\begin{tabular}{|c|l|c|}
\hline No & \multicolumn{1}{|c|}{ Aspek-aspek yang diobservasi } & skor \\
\hline 1 & Kegiatan yang merangsang siswa untuk berpikir & 5 \\
\hline 2 & Suasana pembelajaran & 5 \\
\hline 3 & Reaksi siswa & 5 \\
\hline 4 & Kreativitas siswa & 5 \\
\hline \multicolumn{2}{r|}{ Total skor } & 20 \\
\hline
\end{tabular}

Setelah data terkumpul, kemudian dianalisis dengan metode analisis deskriptif. Langkah-langkah dalam menganalisis data adalah:

1. menentukan skor maksimal ideal (SMI).

2. menentukan skor standar yang diperoleh masing-masing siswa. Teknik yang digunakan adalah konverso PAP sekala 11 yang sudah diadaptasi dengan mengalikan skor tertinggi 10 sehingga skor tertinggi menjadi 100.

3. membuat pedoman konversi seperrti dibawah ini.

Tabel 3. Pedoman Konversi

\begin{tabular}{|c|c|}
\hline Tingkat penguasaan (dalam persen (\%)) & Skor standar \\
\hline $95-100$ & 100 \\
\hline $85-94$ & 90 \\
\hline $75-84$ & 80 \\
\hline $65-74$ & 70 \\
\hline $55-64$ & 60 \\
\hline $45-54$ & 50 \\
\hline $35-44$ & 40 \\
\hline $25-34$ & 30 \\
\hline $15-24$ & 20 \\
\hline $5-14$ & 10 \\
\hline $0-4$ & 0 \\
\hline
\end{tabular}


Berdasarkan hitungan diatas, maka dapatlah ditentukan skor standar yang diperoleh masing-masing siswa. Rentangan skor mentah dan skor standar yang digunakan untuk mengukur kemampuan berpidato siswa adalah

Tabel 4. Rentangan Skor mentah dan skor standar

\begin{tabular}{|c|c|c|}
\hline No & Skor mentah & Skor standar \\
\hline 1 & $95-100$ & 100 \\
\hline 2 & $85-94$ & 90 \\
\hline 3 & $75-84$ & 80 \\
\hline 4 & $65-74$ & 70 \\
\hline 5 & $55-64$ & 60 \\
\hline 6 & $45-54$ & 50 \\
\hline 7 & $35-44$ & 40 \\
\hline 8 & $25-34$ & 30 \\
\hline 9 & $15-24$ & 20 \\
\hline 10 & $5-14$ & 10 \\
\hline 11 & $0-4$ & 0 \\
\hline
\end{tabular}

Standar kompetensi minimal untuk mata pelajaran bahasa Indonesia di Sekolah Dasar Negeri 1 Kukuh Kerambitan tahun pelajaran 2009/2010 adalah 70, tuntas secara klasikal adalah $75 \%$.

\section{HASIL PENELITIAN DAN PEMBAHASAN}

\section{Hasil Tindakan pra Siklus}

Tindakan ini dilakukan dengan memberikan tes pemahaman terhadap pidato dengan perolehan nilai tertinggi 80 , nilai terendah 40 , dan nilai rata - rata yang diperoleh siswa 55,71 dengan kategori cukup. Ini berarti, dari 14 orang siswa baru 2 orang siswa yang memiliki standar ketuntasan minimal dan sisanya perlu diberikan dan dicarikan alternatif pembelajaran yang bisa meningkatkan kemampuan siswa. 


\section{Hasil Tindakan Siklus I}

Pada siklus I ini, siswa diberikan tugas untuk berpidato dengan menerapkan metode demonstrasi. Berdasarkan hasil analisis diperoleh bahwa nilai tertinggi diperoleh oleh 1 orang siswa dengan skor standar 80, sedangkan 4 orang siswa memperoleh nilai 70 dengan persentase $28,57 \%$, dan nilai terendah yaitu 60 diperoleh oleh 9 orang siswa dengan persentase $64,29 \%$, dengan rata - rata kelas $64,29 \%$.

Hasil tersebut belum memenuhi kriteria ketuntasan belajar secara klasikal yang sudah ditentukan. Kesungguhan siswa dalam belajar belum maksimal, siswa belum terbiasa dengan teknik pembelajaran yang diterapkan ini, sihingga siswa tampak kebingungan dalam berbicara di depan kelas.

\section{Hasil Tindakan Siklus II}

Prosedur tindakan siklus II sama dengan yang dilakukan pada siklus I, hanya lebih ditekankan pada penyempurnaan dari hasil tindakan siklus I. Pada siklus II ini, nilai tertinggi diperoleh oleh 4 orang siswa dengan nilai 90, kualifikasi amat baik dan nilai 80 diperoleh juga oleh 4 orang siswa dengan kualifikasi baik, 3 orang siswa memperoleh nilai 70 dengan kualifikasi lebih dari cukup, sedangkan nilai terendah 60 diperoleh oleh 3 orang siswa. Dari semua itu, rata - rata kelas yang diperoleh adalah 76,34 dengan kualifikasi baik. Dengan demikian, dapat dikatakan bahwa hasil yang diperoleh pada siklus II ini telah memenuhi kriteria ketuntasan minimal yang ditentukan. Hasil observasi pada siklus II ini dapat dikatakan bahwa dengan demonstrasi cara berpikir siswa dapat dirangsang, suasana pembelajaran menjadi lebih bergairah, reaksi siswa positif dan siswa lebih aktif melakukan aktivitasnya.

\section{Pembahasan}

Berdasarkan hasil penelitian yang telah diperoleh ditemukan bahwa metode demonstrasi yang diterapkan dalam pembelajaran berbicara dapat meningkatkan kemampuan siswa dalam berpidato. Hal ini terbukti dengan hasil yang diperoleh dari pra siklus sampai siklus ke II yang selalu mengalami peningkatan. Dengan menerapkan metode demonstrasi siswa menjadi lebih kreatif karena suasana pembelajaran yang terbuka dan siswa lebih leluasa melakukan aktifitasnya. 


\section{SIMPULAN}

Berdasarkan analisis hasil dan pembahasan yang telas dilakukan di atas, dapat disimpulkan bahwa penerapan metode demonstrasi dapat meningkatkan kemampuan siswa dalam berpidato. Hal ini terbukti dari hasil yang diperoleh selalu mengalami peningkatan. Hasil pra siklus dengan rata - rata kelas 55,71, meningkat menjadi 64,29 pada siklus I dan pada siklus II meningkat lagi menjadi 76,43. Jadi, dari siklus I ke siklus II terjadi peningkatan yang signifikan yanitu 12,14. Dengan demikian disarankan kepada guru - guru bahasa Indonesia agar menggunakan metode demonstrasi sebagai salah satu alternatif dalam pembelajaran bahasa Indonesia sesuai dengan rencana tindakan yang telah dipaparkan dan dilaksanakan oleh peneliti. Di samping itu, variasi metode pembelajaran perlu diterapkan untuk mencapai hasil yang lebih maksimal.

\section{DAFTAR PUSTAKA}

Alkana, Nesa. 2001. "Meningkatkan Kemampuan Berpidato dengan Media Elektronika pada Siswa Kelas I SMU PGRI 3 UBUD tahun pelajaran 2000/2001".

Arikunto,Suharsimi. 1992. Prosedur Penelitian Suatu pendekatan Praktek. Jakarta: Rineka Cipta

Depdiknas. 2006. Silabus kelas VI SD. Jakarta: Departemen Pendidikan Nasional.

Depdiknas. 2006. KTSP Sekolah Dasar. Jakarta : Departemen Pendidikan Nasional

Firmansyach. 2003. Panduan Lengkap Pidato . Jawa Timur: Galaxy (Bintang Pelajar Group)

Margono. 2000. Metode Penelitian Pendidikan. Jakarta: Rineka Cipta

Sanjaya,Wina. 2006. Strategi Pembelajaran Berorientasi Proses Pendidikan. Jakarta: Kencana

Sumantri, Mulyani,dkk. 1999. Strategi Belajar Mengajar. Jakarta : Depdikbud. 